\title{
An Appraisal of Genus Riccia in India with a Note on Diversity and Distribution of Species
}

\author{
Sushil Kumar Singh \\ Botanical Survey of India, Eastern Regional Centre, Shillong - 793 003, India
}

\begin{abstract}
A review of Indian Riccia's has been made and 36 valid species are accepted. 12 species viz., $R$. attenuata, $R$. ciliata, $R$. crispatula, $R$. crozalsii, $R$. curtisii, $R$. glauca, $R$. haskarliana, $R$. hirta, $R$. mangalorica, $R$. perssonii, $R$. stricta and $R$. warnstorfii are rare and found in restricted pockets of the country. Except Riccia abuensis and $R$. fluitans (aquatic species) all are terrestrial. Riccia poihaiana A.E.D.Daniels \& P.Daniel is proposed to place under synonymy of $R$. billardieri Mont. \& Nees. The occurrence of Riccia squamata, R. duplex and R. dictyospora recorded in Indian bryoflora is treated here doubtful. The notes on Riccia lucknowensis A.Gupta \&Udar and R. nagalandensis D.D.Pant \& Bhowmik ex S.K.Chaturv. \& S.Chaturv. (both invalid species) are given. The taxonomy, diversity and distribution and notes wherever required are provided.
\end{abstract}

Keywords: Marchantiophyta, Riccia, India, Taxonomy, Distribution.

\section{Introduction}

The genus Riccia is the largest genus of thallose liverwort in India. The members the genus are very simple, primitive in morphology and anatomy and characterized by usually linear or oblong thalli differentiated in to photosynthetic and storage zone and with or without simple air pores, sporophytes embedded in the thallus. They differ from the other bryophytes in having fertile plant without involucres, pseudoperianths, seta, cleistocarpous capsules, elaters etc., and occupy unique position in bryophyte systematics. They are unique in their habits in having the tendency to grow in rosettes (a unique feature of the genus)

The earliest record of Riccia from India is found in the posthumous memoirs of William Griffith [1,2] who has given an illustrated account of a species of Riccia from Assam, which is referable to $R$. frostii Austin. Mitten [3] perhaps was the pioneer researcher who dealt comprehensively with Indian Riccia's and reported five species viz $R$. ciliata Hoffm. $R$. crystallina, $R$. discolor Lehm. \& Lindenb., $R$. fluitans L. and $R$. squamata Nees from different part of India. Later, Stephani $[4,5]$ in his world hepatics census reported $R$. discolor, $R$. bulbifera Steph. $\quad(=R$. billardieri Mont. \& Nees $), R$. microspora Steph. (=R. frostii) and $R$. gollani Steph. $(=R$. discolor) from India.

Kashyap [6] instituted five species viz., $R$. pathankotensis Kashyap, $R$. robusta Kashyap (=R. cavernosa Hoffm.), $R$. cruciata Kashyap, $R$. sanguinea Kashyap ( $=R$. frostii) and $R$. himalayensis Kashyap $(=R$. discolor Lehm. \& Lindenb.) mainly from Western Himalyas. Later, he [7] described $R$. melanospora Kashyap from Hoshiarpur and reported $R$ fluitans and Ricciocarpus natans (L.) Corda from Western Himalaya. Ahmad [8] instituted $R$. gangetica Ahmad, $R$. mangalorica Ahmad, and $R$. orientalis Ahmad $(=R$. hirta (Austin) Underw.) from Lucknow, Mangalore and Kumaon respectively. Pande and Ahmad [9] reported R. curtisii (James ex Austin) Austin from Lucknow. Kachroo [10] instituted $R$. kashyapii Kachroo (=R. huebeneriana Lindenb.) from Guwahati and reported $R$. glauca L. from there.

The studies on the genus Riccia in India was in fact accelerated by the Department of Botany, Loucknow University, where Prof. S.K.Pande and Prof. Ram Udar contributed predominantly on the genus of the country and published a series of papers. Udar $[11,12]$ reported $R$. sorocarpa Bisch. and $R$. huebeneriana from Sikkim Himalayas and R. crozalsii Lev., $R$. warnstorfii Limpr. from Ootacamund, South India. Three species, $R$. aravalliensis Pande \& Udar, R. tuberculata Pande \& Udar ( $=R$. grollei Udar) and $R$. attenuata Pande were Instituted from Mount Abu, Nilgiris and Kamakhya Hill respectively by Pande and Udar $[13,14,15]$. Udar $[16,17]$ instituted $R$. pandei Udar and $R$. reticulatula Udar from PauriGarhwal and Pilani, Rajasthan respectively.

Kachroo [18] established a new species, $R$. pimodii Kachroo $(=R$. billardieri $)$ from Burdwan, West Bengal. Bapna [19] described $R$. jodhpurensis Bapna from Jodhpur. Subsequently, Bapna [20] instituted one more species R. abuensis Bapna from

${ }^{*}$ Corresponding author. Tel.: +91 9436705790

Fax: +91 364 2224119; E-mail: sksbsinc@ @rediffmail.com, sksingh@ @si.gov.in

(C) 2014 International Association for Sharing Knowledge and Sustainability

DOI: $10.5383 /$ swes.06.01.0004 
Mount Abu. These records and many other regional ones were reviewed well by Srivastava [21], who accepted occurrence of 29 species of the genus in the country. He provided the detailed account of 18 species and distribution all 29 earlier reported species. In recent years eight species viz., $R$. udarii Kanwal, $R$. indica Udar \& A.Gupta, $R$. lucknowensis A.Gupta \& Udar, $R$. indiragandhii Dabhade \& Akhtar Hasan 'indira-gandhiensis', $R$. nagalandensis D.D.Pant \& Bhowmik ex S.K.Chaturv. \& S.Chaturv., $R$. poihaiana A.E.D.Daniels \& P.Daniel, $R$. velimalaiana A.E.D.Daniels \& P.Daniel, $R$. coracina Jovet-Ast were instituted from different part of the country [22, $23,24,25,26,27,28]$ and three species viz., $R$. perssonii Khan, $R$. stricta (Gottsche, Lindenb. \& Nees) Perold and $R$. haskarliana Steph. [29,30,31] recorded as new to India. A number of regional reports are also published in different journals and books; they are annotated in the distribution of the species in parenthesis.In this study, a total of 36 species are accepted from India. The bryo-geographically they are distributed as below:

Western Himalaya (18): $R$. aravalliensis, $R$. beyrichiana, $R$ billardieri, $R$. cavernosa, R. cruciata, $R$. crystallina, $R$. curtisii, $R$. discolor, $R$. fluitans, $R$. frostii, $R$. gangetica, $R$. hirta, $R$. indica, $R$. melanospora, $R$. pandei, $R$. Pathankotensis, $R$. sorocarpa, $R$. udarii.

Western Ghats (18): R. billardieri, R. coracina, R. crozalsii, $R$ cruciata, $R$. crystallina, $R$. discolor, $R$. fluitans, $R$. frostii, $R$. gangetica, $R$. grollei, $R$. huebeneriana, $R$. indiragandhii, $R$. mangalorica, $R$ melanospora, $R$. sorocarpa, $R$. stricta, $R$. velimalaiana, $R$. warnstorfii.

Eastern Himalaya (16): $R$. attenuata, R. beyrichiana, $R$. billardieri, $R$. cavernosa, $R$. ciliata, $R$. crispatula, $R$. cruciata, $R$. discolor, $R$. fluitans $R$. frostii, $R$. gangetica, $R$. glauca, $R$. haskarliana, $R$. huebeneriana, $R$. sorocarpa, $R$. stricta.

Punjab and West Rajasthan (17): R. abuensis, R. aravalliensis, $R$ billardieri, $R$. cavernosa, $R$. cruciata, $R$. crystallina, $R$. discolor, $R$ fluitans, $R$. frostii, $R$. gangetica, $R$. grollei, $R$. jodhpurensis, $R$. mangalorica, $R$. melanospora, $R$. pathankotensis, $R$. reticulatula, $R$ warnstorfii.

Gangetic plains (14): R. billardieri, R. cavernosa, R. cruciata, $R$ crystallina, $R$. curtisii, $R$. discolor, $R$. fluitans, $R$. frostii, $R$. gangetica, $R$. hirta, $R$. huebeneriana, $R$. melanospora, $R$. perssonii, $R$. sorocarpa

Central India (11): $R$. billardieri, $R$. cavernosa, $R$. crystallina, $R$ discolor, $R$. fluitans, $R$. frostii, $R$. gangetica, $R$. grollei, $R$. huebeneriana, $R$. melanospora, $R$. stricta.

Eastern Ghat \& Deccan Peninsula (7): $R$. billardieri, $R$. ciliata, $R$ coracina, $R$. crispatula, $R$. fluitans, $R$. glauca, $R$. pathankotensis.

Andaman \& Nicobar Islands (1): R. billardieri.

\section{Systematic treatment}

Riccia abuensis Bapna, Trans. Brit. Bryol. Soc. 4: 249. 1962. Distrib.: Rajasthan [20]; endemic.

Riccia aravalliensis Pande \& Udar, J. Indian Bot. Soc. 36: 249. 1957. Distrib.: Rajasthan, Uttarakhand [13]; endemic.

Riccia attenuata Pande in Pande \& Udar in Proc. Natl. Inst. Sci. India 25 B: 92.1959

Distrib.: Assam [15], Sri Lanka [32]

Riccia beyrichiana Hampe in Lehmann, Nov. Stirp. Pug. 7: 1. 1838. Distrib.: Himachal Pradesh [33,34], Meghalaya [21,35], Macronesia [36], Pakistan [37], Russia [38], Africa [39], Europe [40], North America $[41,42]$.

Riccia billardieri Mont. \& Nees in Gottsche, Lindenberg \& Nees, Syn. Hepat. 4: 602. 1846. R. bulbifera Steph., Sp. Hepat. 1: 24. 1900. R. bengalensis Khan in Bryologist 60: 28. 1957. $R$. pimodii Kachroo in J. Indian Bot. Soc. 38: 216. 1959. $R$ himalayensis auct. non Kashyap 1916 sensu Kashyap, Liverw.
W. Himal. 1 (Suppl.): 7. 1932. Riccia poihaiana A.E.D.Daniels \& P.Daniel, Bull. Bot. Surv. India 44: 135. 2002. syn. nov. Distrib.: Andaman [43], Assam [15], Gujarat [44], Himachal Pradesh [45], Jharkhand [4], Karnataka [14,21], Kerala [30], Madhya Pradesh [46, 21], Maharashtra [21], Manipur [47], Rajasthan [48], Sikkim [31], Tamil Nadu [21, 26], Uttar Pradesh $[21,49,50]$, Uttarakhand [16,21], West Bengal $(4,10$, 21,51,52,53], Bangladesh [54], Indonesia [55], Nepal [56], Philippines [57], Sri Lanka [32], Thailand [58], Australia [59].

Notes: Riccia poihana was described from Poihai reservoir, Kanyakumari, Tamil Nadu by Daniels and Daniel [26]. A study of type (P. Daniel 01!) deposited at Herbarium of Botanical Survey of India, Southern Regional Centre, Coimbatore (MH) reveals it is not different than the Riccia billardieri. Hence, $R$. poihana is proposed to synonym de novo of Riccia billardieri here.

Riccia cavernosa Hoffm., Deutschl. Fl. 2: 95.1796 emend. Raddi, Opusc. Sci. (Bologna) 12: 351. 1818. R. robusta Kashyap, J. Bombay Nat. Hist. Soc. 24: 348. 1916.

Distrib.: Himachal Pradesh [7], Madhya Pradesh [60]), Nagaland [28], Uttar Pradesh [7,61], Rajasthan [48], Bangladesh [62], Iran [63], Macronesia [36] Nepal [56], Pakistan [6], Russia [38], Africa [64], Australia [59], Europe [40], North America [42] South America [65].

Riccia ciliata Hoffm., Deutschl. Fl. 2 (Cryptog.): 95. "1795" 1796. Riccia trichocarpa M.Howe Bull. Torrey Bot. Club 25: 184. 1898

Distrib.: Odisha [66] Sikkim [21], West Bengal [3], Iran [63], Macronesia [36], New Zealand [67] Russia [38], Turkey [68], Africa [64], Europe [40], North America [42] South America [65].

Riccia coracina Jovet-Ast, Cryptog. Bryol. 24: 212. 2003. Distrib.: Tamil Nadu [27], endemic.

Riccia crispatula Mitt., Proc. J. Linn. Soc., Bot. 5: 127. 1861. Distrib.: Odisha (69), West Bengal [70], Sri Lanka [32].

Riccia crozalsii Lev. in Rev. Bryol. 29: 73. 1902.

Distrib.: Tamil Nadu [12], Iran [63], Macronesia [36], New Zealand [67], Turkey [68], Africa [64], Australia [59], Europe [40].

Riccia cruciata Kashyap, J. Bombay Nat. Hist. Soc. 24: 349. 1916.

Distrib.: Kerala [21], Maharashtra [71], Nagaland [28], Punjab [6,7], Uttarakhand [72,73,33], Uttar Pradesh [21,49], West Bengal [74], Indonesia [27], Pakistan [6,7].

Riccia crystallina L. Sp. Pl.: 1138. 1753 emend. Raddi, Opusc. Sci. (Bologna) 12: 353. 1818. Riccia plana Taylor, London J. Bot. 5: 414. 1846.

Distrib.: Jammu \& Kashmir [75], Karnataka [14], Kerala [30], Maharashtra [71], Madhya Pradesh [61,77], Punjab [78], Uttar Pradesh [49]; Rajasthan [48,79], West Bengal (Singh et al., as R. plana) [74], Bangladesh [62], China [80] Macronesia 

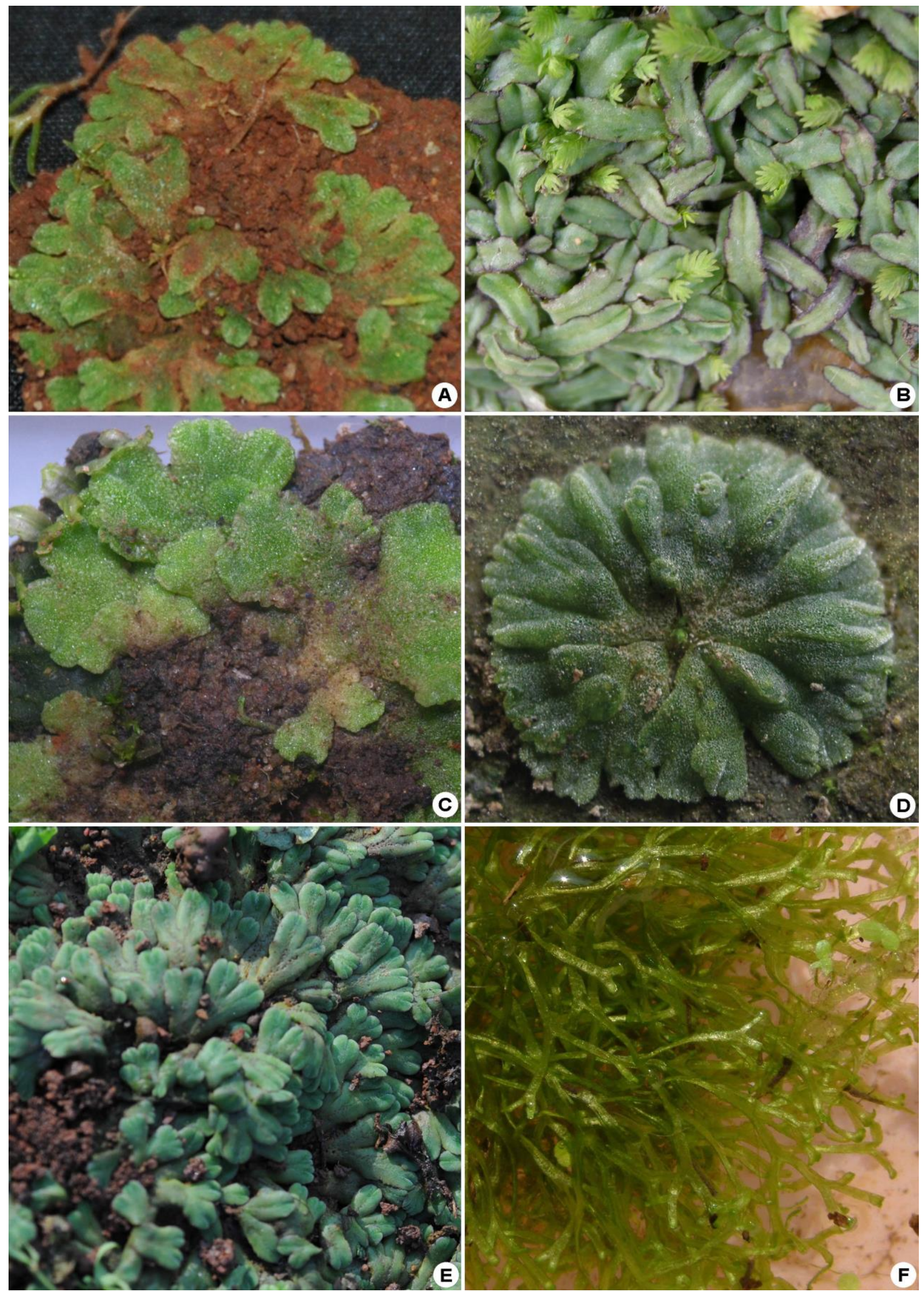

Fig. 1: A. R. beyrichiana, B. R. billardieri, C. R. cruciata, D. R. cavernosa, E. R. crystallina, F. R. fluitans. 

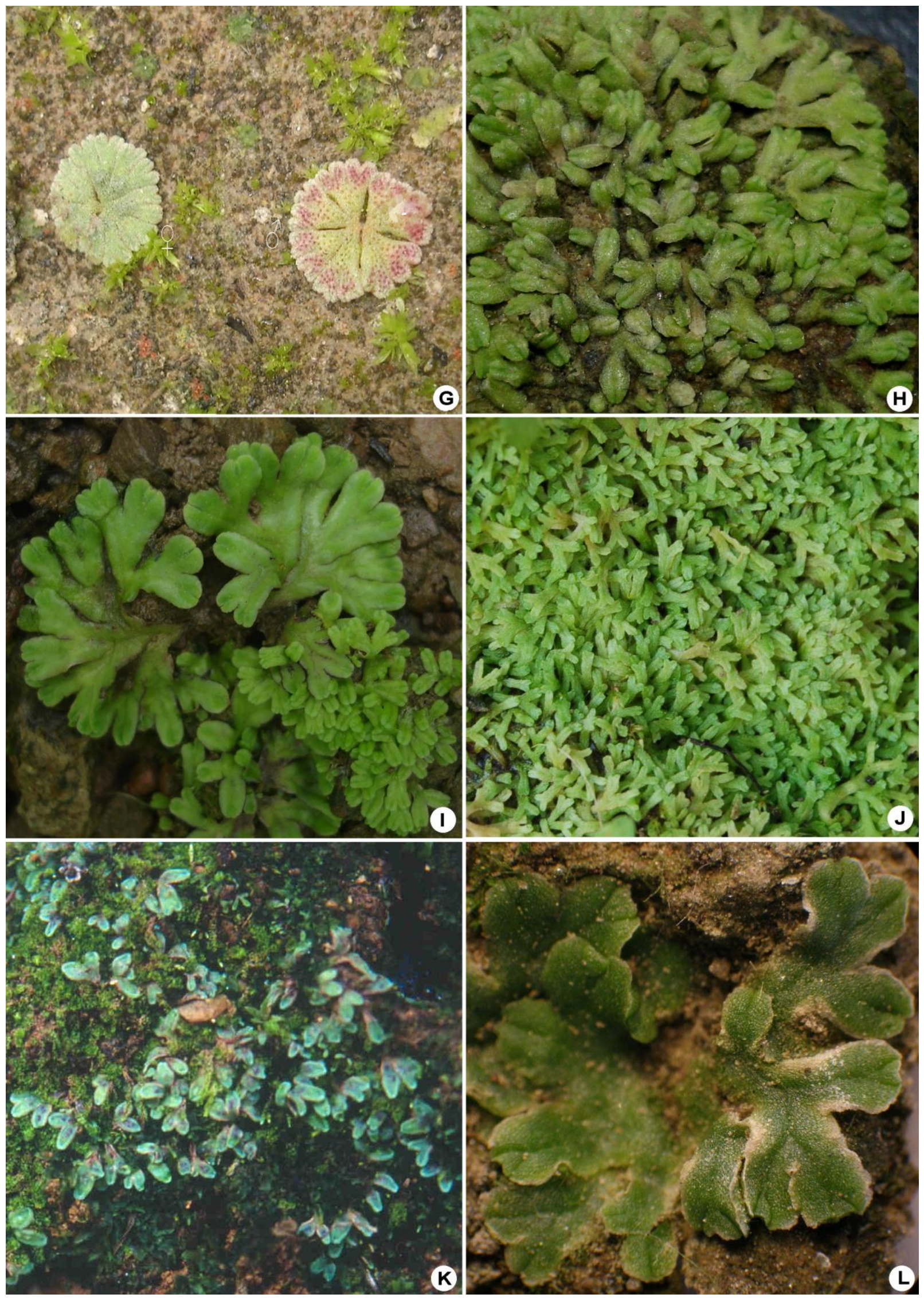

Fig. 2: G. R. frostii, H. R. gangetica, I. R. glauca, J. R. huebeneriana, K. R. pathankotensis, L. R. sorocarpa. 
[36], New Zealand [67], Turkey [68], Africa [64], Australia [59], Europe [40], North America [42], South America [65].

Riccia curtisii (James ex Austin) Austin, Bull. Torrey Bot. Club 6: 305. 1879. Cryptocarpus curtisii James ex Austin, Proc. Acad. Natl. Sci. Philadelphia 21: 231. 1870.

Distrib.: Uttarakhand [81], Uttar Pradesh [21], Africa [64], North America [42], South America [65].

Riccia discolor Lehm. \& Lindenb. in Lehmann, Nov. Stirp. Pug. 4: 1. 1832. R. himalayensis Kashyap, J. Bombay Nat. Hist. Soc. 24: 349. 1916. R. gollanii Lev. ex Steph., Sp. Hepat. 6: 2.1924.

Distrib.: Assam [21], Chattishgarh [82], Gujarat [44], Himachal Pradesh [7], Jammu \& Kashmir [75], Karnataka [21], Kerala [83], Maharashtra [71], Meghalaya [21], Madhya Pradesh [21,46,77], Punjab [7,52], Rajasthan [48,79], Sikkim [84], Tamil Nadu [7,21], Uttarakhand [6, 21], Uttar Pradesh [21,49] West Bengal [74], Bangladesh [85], Myanmar [7], Nepal [86], Pakistan [7], Sri Lanka [32] Africa [64], Australia [59],

Riccia fluitans L., Sp. Pl.: 1139. 1753. Fysonia tenera Kashyap, Liwerw. W. Himal. 1: 97. 1929. Riccia media Klingm., Flora. 146: 616-624. 1958.

Distrib.: Chattishgarh [82], Himachal Pradesh [87], Jammu \& Kashmir [7], Maharashtra [52,71], Meghalaya [21], Madhya Pradesh [77], Odishsa [66], Rajasthan [48], Sikkim [84],Tamil Nadu [88], Uttarakhand [3,7,73], Uttar Pradesh [49], Afghanistan [89], Bangladesh [62], Bhutan [90], China [80], Hawaii [91], Indonesia [92], Iran [63], Japan [93] Korea [94], Nepal [56], New Zealand [67], Pakistan [7], Russia [38], Thailand [58], Turkey [68], Africa [64], Europe [40], North America [42].

Note: This is a cosmopolitan species of the genus found in aquatic habitat. Very recently, Manju et al. [95] has advocated that plants recorded as $R$. fluitans from various Indian regions are of $R$. stricta. However, it may be annotated here that if we follow the differentiating character used by Manju et al. (l.c.) for differentiating $R$. fluitans from $R$. stricta (Thallus with small air chambers with distinct areolate walls; spore production very rare- $R$. fluitans) then the reports, atleast of Kashyap [7], Srivastava [21] and Singh \& Singh [73] definitely belong to Riccia fluitans. Hence, there is no doubt about the occurrence of $R$. fluitans in Indian region. The reports from Kerala may belong to $R$. stricta as suggested. A further thorough investigation of Indian plants of $R$. fluitans and $R$. stricta are required to clarify more the situation.

Riccia frostii Austin, Bull. Torrey Bot. Club 6: 17. 1875. R. sanguinea Kashyap, J. Bombay Nat. Hist. Soc. 24: 349. 1916. R. microspora Steph., Sp. Hepat. 1: 43. 1900.

Distrib.: Assam [96] Bihar [97] Delhi [52], Jharkhand (present record); Jammu \& Kashmir [97], Kerala [98], Maharashtra [71], Manipur [47], Madhya Pradesh [97], Punjab [78], Rajasthan [48], Sikkim [21], Tamil Nadu [7], Uttarakhand [72, 73], Uttar Pradesh [7,49], West Bengal [99], Bangladesh [62], China [80], Iran [63], Nepal [56], Pakistan [7], Russia [38], Turkey [68], Africa [64], Europe [40], North America [42], South America [65].

Riccia gangetica Ahmad ex L.Söderstr., A.Hagborg et von Konrat, Phytotaxa 65: 57. 2012.

Distrib.: Gujarat [44], Himachal Pradesh [86], Kerala [83], Maharashtra [71], Madhya Pradesh [100,76], Meghalaya (15,21); Rajasthan [48], Uttarakhand [16], Tamil Nadu [88], Uttar Pradesh [8,49], West Bengal [70], Bangladesh [85] Indonesia [92], Australia [59].
Riccia glauca L., Sp. P1.: 1139. 1753. var. glauca

Distrib.: Assam [53, 101], Odisha [66], China [80], Iran [63], Turkey [68], Taiwan [102], Korea [94], Japan [93], Russia [38], Macronesia [36], New Zealand [67], Africa [64], Europe [40], North America [41].

Riccia grollei Udar, Curr. Sci. 34: 126. 1965. R. tuberculata Pande \& Udar, Proc. Natl. Inst. Sci. India 24 B: 83. 1958.

Distrib.: Gujarat [44], Madhya Pradesh [76], Rajasthan [103, 79], Tamil Nadu [14,88], endemic.

Riccia haskarliana Steph., Bull. Herb. Boiss. 6: 374. 1898. Distrib.: Sikkim [31], Indonesia [92,104].

Riccia hirta (Austin) Underw., Bot Gaz. 19: 274. 1896. R. orientalis Ahmad, Curr. Sci. 11: 433. 1942.

Distrib.: Uttarakhand [16], Uttar Pradesh [49], North America [42].

Riccia huebeneriana Lindenb., Nova Acta Phys.-Med. Acad. Caes. Leap.-Carol. Nat. Cur. 18: 504d. "1836" 1837. $R$. kashyapii Kachroo, Sci. \& Cult. 20: 98. 1954.

Distrib.: Assam [10,21,101], Chattishgarh [82], Karnataka [21], Kerala [30], Madhya Pradesh [11,105], Sikkim [21], Uttar Pradesh [49], West Bengal [11,21,74], China [80], Japan [93] Korea [94], Macronesia [36], Phillipines [57], Russia [38], Europe [40], Africa [64], North America [42].

Riccia indica Udar \& A.Gupta, Proc. V. Indian Geophytol. Conf., Lucknow (1983), Spl. Publ. 307. 1984.

Distrib.: Uttarakhand [23], endemic.

Riccia indiragandhii Dabhade \&Akhtar Hasan, J. Bombay Nat. Hist. Soc. 83: 398. 1986. 'indira-gandhiensis' Distrib.: Maharashtra [25], endemic.

Riccia jodhpurensis Bapna, Bot. Not. 114: 181. 1961. Distrib.: Rajasthanr [19], endemic.

Riccia mangalorica Ahmad ex Jovet-Ast, Cryptog. Bryol. 24: 223. 2003.

Distrib.: Karnataka [8], Rajasthan [27], Indonesia [27].

Riccia melanospora Kashyap, Liwerw. W. Himal. 1: 94.1929. Distrib.: Jammu \& Kashmir (21,52); Maharashtra [71], Madhya Pradesh [76], Punjab [7], Rajasthan [79,103], Tamil Nadu [14,21], Uttarakhand [21], Uttar Pradesh [21,49], West Bengal [70], Bangladesh [62], Pakistan [106].

Riccia pandei Udar, J. Indian Bot. Soc. 38: 149. 1959.

Distrib.: Uttarakhand [16,72], endemic.

Riccia pathankotensis Kashyap, J. Bombay Nat. Hist. Soc. 24: 349. 1916

Distrib.: Himachal Pradesh [7,107], Odisha [66], Punjab [52], Uttarakhand [21,72], Nepal [56], Pakistan [7].

Riccia perssonii Khan, Svensk Bot. Tidskr. 49: 433. 1955.

Distrib.: Uttar Pradesh [29], West Bengal [74], Bangladesh [62], Africa [64].

Riccia reticulatula Udar, Bull. Bot. Soc. Univ. Saugar. 13: 49. 1961.

Distrib.: Rajasthan [17], endemic.

Riccia sorocarpa Bisch., Nova Acta Phys.-Med. Acad. Caes. Leop.-Carol. Nat. Cur. 17: 1053. 1835. var. sorocarpa Distrib.: Himachal Pradesh [11], Uttarakhand [33], Tamil Nadu [88], West Bengal [11,74, Bangladesh [85], China [80], Hawaii [91], Iran [63], Japan [93], Korea [94], Macronesia [36], New Zealand [67], Russia [38], Turkey [68], Africa [64], 
Australia [59], Europe [39], North America [41], South America [65].

Riccia stricta (Gottsche, Lindenb. \& Nees) Perold, Bothalia 20: 197. 1990. R. fluitans var. stricta Gottsche, Lindenb. \& Nees, Syn. Hepat. 610.1846

Distrib.: Kerala [30], Madhya Pradesh [60], Sikkim [31], Tamil Nadu [95], West Bengal [74], Africa [64].

Riccia udarii Kanwal, J. Indian Bot. Soc. 58: 282. 1979.

Distrib.: Uttarakhand [22], endemic.

Note: This species approaches Riccia fluitans in its aquatic habitat and thallus structure. A study of type material may concatenate the two species.

Riccia velimalaiana A.E.D.Daniels \& P.Daniel, Bull. Bot. Surv. India 44: 139. 2002.

Distrib.: Tamil Nadu [26], endemic.

Notes: Riccia velimalaiana was described from Velimalai, Kanyakumari, Tamil Nadu by Daniels and Daniel [26]. A study of type (A.E.D. Daniels 921!) deposited at Herbarium of Botanical Survey of India, Southern Regional Centre, Coimbatore $(\mathrm{MH})$ reveals it is similar to Riccia grollei Udar. The features used by authors to differentiate it from $R$. grollei falls in range of variations except a typical feature of $R$. grolle $i$ thallus which assimilatory filaments of cell walls bears tuberculate thickening (not noticed by the authors). A further study of type of Riccia grollei may lead to interesting findings.

Riccia warnstorfii Limpr. in Warnstorf, Verh. Bot. Ver. Prov. Brandenb. 27: 85. 1885.

Distrib.: Tamil Nadu [12, 14], Punjab [78], Macronesia [36], Pakistan [37], Africa [64], Europe [40].

\subsection{Doubtful Records}

Riccia dictyospora M. Howe, Bull. Torrey Bot. Club 28 (3): 163. 1901.

Note: This species was reported by Udar [108] from Lucknow (U.P.) India. This report was published in a form of abstract and no detailed description was provided. Later, it could not be reported form any other locality of the country. However, about a decade later, Udar [17] reviewed the status of Riccia's in Central-India Zone, Gangetic Plains, Punjab and Rajasthan and provided a detailed taxonomic account of the genus Riccia growing there but without mention of $R$. dictyospora. Therefore, the report of this species from Lucknow is not tenable and as such the occurrence of this species from Indian regions is treated here doubtful.

Riccia duplex Lorb. \& Müll. Frieb., Hedwigia 80: 100. 1941. Note: This species was recorded from along the margins of Khajiar lake, Dalhousie Himachal Pradesh India. While reporting this species authours annotated that this species is probably terrestrial form of Riccia fluitans [87]. Later, this species could not be reported from elsewhere in India. The plants collected from Khajiar lake are apparently destroyed (Prof. S.S. Bir: pers. comm.) and are not available for further study. Hence the occurrence of this species in India is untenable.

Riccia squamata Nees in Mart., Fl. Bras. 1: 302. 1833.

Note: This species is reported by Mitten (1861) without any definite locality in India. Later, it could not be collected from anywhere else in India. Hence in dearth of further collection of it is treated as doubtful record.

\subsection{Invalid Species}

Riccia nagalandensis D.D.Pant \& Bhowmik ex S.K.Chaturv. \& S.Chaturv., Bryology in the New Millennium p. 88, 2008, nom. inval.

Note: This species was initially published in form of abstract (Pant \& Bhowmik, 1997: Abst. p. 4), and presented in a symposium "National Symposium of Biodiversity, Conservation and Evolution of Plants" organized by Department of Botany, Allahabad University, Allahabad. This is an invalid publication as it does not fulfill the requirement for valid publication (Art. 39.1 \& 40.1: Melbourne Code). Chaturvedi and Chaturvedi (2008) reported again it from Mokokchung, Nagaland without validating the same.

Riccia lucknowensis A.Gupta \& Udar, Bryophyt. Biblioth.29: 51. 1986, nom. inval.

Note: This species was instituted on the basis of the collection Mashidha, Malihabad near Lucknow Uttar Pradesh (Gupta \& Udar, 1986). The authors had provided only the spore descriptions not the other details. Following the rules of ICBN, this is an invalid publication as it does not fulfill the requirement for valid publication (Art. 39.1 \& 40.1: Melbourne Code).

\section{Conclusion}

Genus Riccia is the largest among thallose liverworts in India. A detailed review of Riccia's growing in different geographical location of the country has been made after a long gap of 46 year and 36 valid species are accepted from India. From diversity point of view, the Western Himalaya and Western Ghats are rich with 18 species each. However, the species are also luxuriously growing in low elevated/plain areas of Punjab $\&$ West Rajasthan, Gangetic plains and central India. Species are mostly terrestrial in habit. The current data on diversity, distribution and taxonomy is discussed. About $1 / 3$ of the known species (11 species) are endemic to the country. These are: Riccia abuensis, $R$. aravalliensis, $R$. coracina, $R$. grollei, $R$. indica, $R$. indiragandhii, $R$. jodhpurensis, $R$. pandei, $R$. reticulatula, $R$. udarii, $R$. velimalaiana. Riccia poihaiana A.E.D.Daniels \& P.Daniel, a species recently described [26] from Western Ghat shows no remarkable difference from $R$. billardieri Mont. \& Nees, hence former synoymised under the latter here. Three species viz., Riccia squamata, $R$. duplex and $R$. dictyospora are excluded from Indian bryoflora as their occurrence is doubtful (see notes under mentioned species).

\section{Acknowledgments}

Author is thankful to the Director, Botanical Survey of India, Kolkata for facilities; Dr D.K. Singh, Addl. Director, BSI, Kolkata for review, suggestions and photo of Riccia crystallina; Scientist-E \& H.O.O., BSI, Eastern Regional Centre, Shillong for encouragement.

\section{References}

[1] Griffith, W. Notulae ad Plantas Asiaticas II. Government of Bengal, Calcutta. 1849.

[2] Griffith, W. Icones Plantarum Asiaticarum II Government of Bengal, Calcutta. 1849.

[3] Mitten, W. Hepaticae Indiae Oreintalis, an enumeration of the Hepaticae of East Indies. Journal of the proceedings of the Linnean Society, Botany. 5: 89128. 1861. 
[4] Stephani, F. Species Hepaticarum I. Georg et Cie, Lyon, même Maison, Genève \& Bale. 1900.

[5] Stephani, F. Species Hepaticarum VI. Georg et Cie, Lyon, même Maison, Genève \& Bale. 1917-1924.

[6] Kashyap, S.R. Liverworts of the Western Himalayas and the Punjab, with notes on known species and descriptions of new species. The Journal of the Bombay Natural History Society 24: 343-350. 1916.

[7] Kashyap, S.R. Liverworts of the Western Himalayas and the Panjab Plain I. The University of the Panjab, Lahore. 1929.

[8] Ahmad, S. Three new species of Riccia from India. Current Science 11: 433-434. 1942.

[9] Pande, S.K. and Ahmad, S. Liverworts of Lucknow and its neighbourhood. Proceedings of the $31^{\text {st }}$ Indian Science Congress, part 3, p. 80. 1944

[10] Kachroo, P. Studies in Assam Hepaticae. II. On a new species of Anthoceros L. \& Riccia L. Science \& Culture 20: 98-101. 1954.

[11] Udar, R. On the two species of Riccia new to Indian flora. Current Science 25: 232-233. 1956.

[12] Udar, R. Riccia crozalsii Levier and Riccia warnstorfii Limpr. from India. Current Science 26: 287-288. 1957.

[13] Pande, S.K. and Udar, R. A species of Riccia, R. aravalliensis Pande et Udar sp. nov., from Mt. Abu, Rajasthan, India. Journal of the Indian Botanical Society 36: 248-253. 1957.

[14] Pande, S.K and Udar, R. Genus Riccia in India. II. Speices of Riccia from South India with description of a new species and notes on the synonymy of some recently described ones. Proceedings of the National Institute of Sciences of India 24 B: 79-88. 1958.

[15] Pande, S.K. and Udar, R. Genus Riccia in India. III. Species of Riccia from the East Himalayan territory with description of a new species, $R$. attenuata Pande sp. nov. Proceedings of the National Institute of Sciences of India 25 B: 90-100. 1959.

[16] Udar, R. Genus Riccia in India. IV. A new Riccia, Riccia pandei Udar sp. nov., from Garhwal with a note on the species of the genus from the West Himalayan territory. Journal of the Indian Botanical Society 38: 146-159. 1959.

[17] Udar, R. Genus Riccia in India V. A new Riccia. R. reticulatula Udar sp. nov., from Pilani with a note on the species of Riccia from the Central India zone, Gangetic plains, Panjab and Rajasthan. Bulletin of the Botanical Society of the University of Saugar 13: 46-55. 1961.

[18] Kachroo, P. Hepaticae of Bengal. I. Sporeling germination and taxonomy of Riccia pimodii sp. nov. from Burdwan. Journal of the Indian Botanical Society 38: 213-220. 1959.

[19] Bapna, K.R. A new species of Riccia from Jodphur (India), R. jodhpuriensis sp. nov. Botaniska Notiser 114: 181-184. 1961.

[20] Bapna, K.R. A new species of Riccia from Mount Abu (India). Transactions of the British Bryological Society 4: 249-253. 1962
[21] Srivastava, K.P. Bryophytes of India I. Ricciaceae Bulletin of the National Botanical Gardens, Lucknow 104: 1-103. 1964

[22] Kanwal, H.S. A new species of Riccia L., R. udarii sp. nov., from kumaon (Western Himalayas) India. Journal of the Indian Botanical Society 58: 281-285. 1979.

[23] Udar, R. and Gupta, A. A new Riccia (Mich.) L. from Deoban, Western Himalayas, India. Proceedings of $5^{\text {th }}$ Indian Geophytological Conference, Lucknow (1983), Special Publication pp. 307-311. 1984.

[24] Gupta, A. and Udar, R. Palyno-taxonomy of selected Indian liverworts. Bryophytorum Bibliotheca 29: 1-141. 1986.

[25] Dabhade, G.T. and Hasan, A. New species of Riccia - $R$ indiragandhiensis sp.nov. Journal of the Bombay Natural History Society 83: 398-400. 1986.

[26] Daniels, A.E.D. and Daniel, P. Two new species of Riccia L. (Hepaticae: Marchantiales) from the Western Ghats of Tamil Nadu. Bulletin of the Botanical Survey of India 44: 135-140. 2002.

[27] Jovet-Ast, S. Riccia des sous-genres Riccia et Ricciella récoltés en Inde et en Indonésie. Cryptogamie Bryologie 24: 209-228. 2003

[28] Chaturvedi, S.K. and Chaturvedi, S. Diversity of thalloid liverworts in Mokokchung and Zunheboto district, Nagaland, India. In: Mohamed H, Baki BB, NasrulhaqBoyce A, Lee PKY, eds. Bryology in the New Millennium. Kuala Lumpur: University of Malaya, pp. 83-91. 2008

[29] Sahai, R. and Sinha, A.B. Riccia perssonii Khan -a new record for India. Current Science 42: 226-227. 1972.

[30] Udar, R. and Jain, A. Liverworts of Kerala-I Marchantiales. Indian Journal of Forestry 7: 300-304. 1984.

[31] Dey, M., Singh, D. and Singh, D.K. Some new and noteworthy records of hepaticae from eastern Himalaya, India. Indian Journal of Forestry 32: 669-684. 2009.

[32] Abeywickrama, B.A. and Jansen, M.A.B. A check list of the liverworts of Sri Lanka. UNESCO: Man and the Biosphere National Committee for Sri Lanka 1: 1-10. 1978.

[33] Singh, S.K. and Singh, D.K. Some new and noteworthy records of Hepaticae and Anthocerotae from Western Himalaya, India Cryptogamie Bryologie 28: 253-265. 2007.

[34] Singh, S.K. and Singh, D.K. Hepaticae and Anthocerotae of Great Himalayan National Park and its environs (H.P.), India. BSI, Kolkata. 2009

[35] Singh, A.P. and Nath, V. Hepaticae of Khasi and Jaintia Hills: Eastern Himalayas. Bishen Singh Mahendra Pal Singh, Dehradun. 2007.

[36] Söderström, L., Urmi, E. and Váňa, J. Distribution of Hepaticae and Anthocerotae in Europe and Macaronesia. Lindbergia 27: 3-47. 2002.

[37] Furuki, T., Yamada, K., Hattori, S. and Nishimura, N. Hepaticae collected from Pakistan in 1991. In: T. Nakaike and S. Malik (eds.), Cryptogamic flora of Pakistan. National Science Museum, Tokyo Vol 2 pp. 221-229. 1993. 
[38] Konstantinova, N.A., Baklin, V.A., Andrejeva, E.N., Bezgodov, A.G., Borovichev, E.A., Dulin, M.V. and Mamontov, Yu. S. Checklist of liverworts (Marchantiophyta) of Russia. Arctoa 18: 1-64. 2009.

[39] Ros, R.M., Mazimpaka, V., Abou-Salama, U., Aleffi, M., Blockeel, T.L., Brugués, M., Cano, M.J., Cros, R.M., Dia, M.G., Dirkse, G.M., Saadawi, W.E., Erdağ, A., Ganeva, A., González-mancebo, J.M., Herrnstadt, I., Khalil, K., Kürschner, H., Lanfranco, E., Losada-Lima A., Refai, M.S., Rodríguez-nuñez, S., Sabovljevic, M., Sérgio, C., Shabbara, H., Sim-Sim, M. and Söderström, L. Hepatics and Anthocerotes of the Mediterranean, an annotated checklist. Cryptogamie Bryologie 28: 351-437. 2007.

[40] Söderström, L., Urmi, E. and Váňa, J. The distribution of Hepaticae and Anthocerotae in Europe and Macaronesia Update 1-427. Cryptogamie Bryologie 28: 299-350. 2007.

[41] Stotler, R.E., and Stotler, B.C. A checklist of the liverworts and hornworts of North America. The Bryologist 80: 405-428. 1977.

[42] Schuster, R.M. The Hepaticae and Anthocerotae of North America (East of the Hundredth Meridian) VI. Field Museum of Natural History, Chicago. 1992.

[43] Singh, S. K., Roy, S.K. and Bag, A. K. Two new and noteworthy records of thalloid liverwort from Andaman islands, India. Indian Journal of Forestry 32: 327-330. 2009.

[44] Chaudhary, B.L., Sharma, T.P. and Sanadhya, C. Bryophyte flora of Gujarat (India). Himanshu Publ., Udaipur, India. 2006.

[45] Bir, S.S. Thallose liverworts from Simla, North Western Himalayas. Science \& Culture 41: 272-274. 1975.

[46] Bhargava, H.R. and Thampi, G.V. Studies on the liverworts of Sagar I. A contribution to liverwort flora of Sagar. Madhya Bharti 9: 61-85. 1960.

[47] Singh, D., Dey, M. and Singh, D.K. A synoptic flora of liverworts and hornworts of Manipur. Nelumbo 52: 9-52. 2010 .

[48] Bapna, K.R. A note on hepatic flora of Mt. Abu. Current Science 27: 259-260. 1958

[49] Sinha, A.B., Singh, U.S. and Shukla, M.S. Genus Riccia (Mich.) L. of district Gorakhpur. Journal of Economic and Taxonomic Botany 14: 201-203. 1990.

[50] Singh, S.K. and Kumar, S. A Note on bryophytes of Ram Nagri (Ayodhya), Faizabad, Uttar Pradesh, India. Phytotaxonomy 3: 108-111. 2003.

[51] Singh, S.K. and Ghosh, J.P. Bryo-diversity in Indian Botanic Garden, Howrah, West Bengal. Bulletin of the Botanical Survey of India 49: 155-164. 2007.

[52] Kashyap, S.R. Liverworts of the Western Himalayas and the Panjab Plain II. The University of the Panjab, Lahore. 1932.

[53] Kachroo, P. Studies in Assam Hepaticae. IV. On some species of Anthoceros L., Notothylas Sull. and Riccia L. from eastern India. Journal of the University Gauhati 5: 124-133. 1954.

[54] Khan, S.A. Studies in Ricciaceae of East Pakistan. I. New and little known species of Riccia. The Bryologist 60: 2832. 1957 .
[55] Gradstein, S.R., Tan, B.C., Zhu, R.L., Ho, B.-C., King, C., Drübert, C. and Pitopang, R. A catalogue of the bryophytes of Sulawesi, Indonesia. Journal of the Hattori Botanical Laboratory 98: 213-257. 2005.

[56] Pradhan, N. and Joshi, S.D. Liverworts and hornworts of Nepal: a synopsis. Botanica Orientalis 6: 69-75. 2009.

[57] Tan, B. C. and Engel, J.J. An annotated checklist of Philippine Hepaticae. Journal of the Hattori Botanical Laboratory 60: 283-355. 1986.

[58] Lai, M.J., Zhu, R.L. and Chantanaorrapint, S. Liverworts and hornworts of Thailand: an updated checklist and bryofloristic accounts Annales Botanici Fennici 45: 321 341. 2008.

[59] McCarthy, P.M. Checklist of Australian Liverworts and Hornworts. Australian Biological Resources Study, Canberra. Version 6 April 2006 http://www.anbg.gov.au/abrs/liverwortlist/liverworts_intr o.html. 2006.

[60] Udar, R. and Agarwal, A. The genus Riccia in Pachmarhi with SEM details of spores of two species. Journal of the Indian Botanical Society 64: 246-250. 1985.

[61] Pande, S.K. On the morphology of Riccia robusta Kash. Journal of the Indian Botanical Society 12: 110-121. 1933.

[62] Banu-Fattah, K. A comprehensive checklist of bryophytes of Bangladesh. Bangladesh Journal of Plant Taxonomy 8: 7-18. 2001

[63] Akhani, H. and Kürschner, H. An annotated and updated checklist of the Iranian bryoflora. Cryptogamie Bryologie 25: 315-347. 2004.

[64] Wigginton, M. J. Checklist and distribution of the liverworts and hornworts of sub-Saharan Africa, including the East African Islands. Tropical Bryology Research Reports 8: 1-116. 2009.

[65] Bischler, H., Gradstein, S.R., Jovet-Ast, S. Long, D.G. and Salazar Allen, N. Marchantiidae. Flora Neotropica Monograph 97: 1-262. 2005.

[66] Dash, P.K. and Saxena, D.K. Bryoflora of Khandadhar hill ranges, Orissa, India. Geobios 36: 713-116. 2009.

[67] Glenny, D. A revised checklist of New Zealand liverworts and hornworts. Tuhinga 10: 119-149. 1998.

[68] Kürschner, H. and Erdağ, A. Bryophytes of Turkey: An Annotated Reference List of the Species with Synonyms from the Recent Literature and an Annotated List of Turkish Bryological Literature. The Turkish Journal of Botany 29: 95-154. 2005

[69] Chopra, R.S. A census of Indian hepatics. Journal of the Indian Botanical Society 22: 237-249. 1943.

[70] Bag, A.K., Singh, S.K. and Bhattacharya, S.G. Riccia of West Bengal. Bulletin of the Botanical Survey of India 49: 173-186. 2007

[71] Joshi, D.Y. and Biradar, N.V. Studies in the liverwort flora of Western Ghats with special reference to Maharashtra, India. Journal of the Hattori Botanical Laboratory 56: 45-52. 1984

[72] Gaur, R.D. and Nautiyal, S. Thallose liverworts from Srinagar and adjacent areas. 1. Indian Journal of Forestry 4: 75-76. 1981 . 
[73] Singh, S.K. and Singh, D.K. A preliminary census of Hepaticae and Anthocerotae of Doon Valley. Bulletin of the Botanical Survey of India 49: 1-14. 2007.

[74] Singh, S. K., Bag, A. K. and Bhattacharya, S. G. Riccia (Hepaticae: Ricciaceae) of West Bengal. Taiwania 55: 99-109. 2010.

[75] Langer, A., Gupta, S. and Tanwir, M. Preliminary survey of Jammu district (North West Himalaya) for liverwort and hornwort flora. Geophytology 31: 87-89. 2003

[76] Saxena, S.D. and Handoo, O.N. A note on Cryptogams of Bhopal. Current Science 30: 31-32. 1961.

[77] Gautam, S.P. and Thakur, M.K. A note on the distribution of Hepaticae in Jabalpur, Madhya Pradesh (India). Journal of Economic and Taxonomic Botany 2: 195-196. 1981.

[78] Singh, D.K., Singh, S.K., Kumar, S. and Gaur, R.D. Bryodiversity in Shivalik Ecosystems of Punjab. Journal of Economic and Taxonomic Botany 30: 624-632. 2006.

[79] Bapna, K.R. A note on Hepntics of Udaipur. Science \& Culture 32: 526. 1965.

[80] Piippo, S. Annotated catalogue of Chinese Hepaticae and Anthocerotae. Journal of the Hattori Botanical Laboratory 68: 1-192. 1990

[81] Tewari, S.D. and Pant, G.B. Riccia curtisii (Aust.) James, from Kumaon Himalayas. Current Science 52: 164-165. 1983.

[82] Lal, J. and Parihar, N.S. Contributions to the bryoflora of Central Indian Zone 1- Liverworts. Journal of the Indian Botanical Society 58: 110-114. 1979.

[83] Manju, C.N., Rajesh, K.P. and Madhusoodanan, P.V. Checklist of the bryophytes of Kerala, India. Tropical Bryology Research Reports 7: 1-24. 2008.

[84] Singh, D.K., Singh, D. and Dey, M. A Catalogue of the Hepaticae and Anthocerotae of Sikkim. In: Mohamed, H., Baki B.B., Nasrulhaq-Boyce. A., Lee. P.K.Y. (eds.), Bryology in the New Millennium. Kuala Lumpur, University of Malaya. pp. 93-135. 2008.

[85] Banu-Fattah, K. and Sarker S.K. Bryophyte flora of greater Mymensingh district of Bangladesh- Class: Hepaticopsida and Anthocerotopsida. Bangladesh Journal of Plant Taxonomy 17: 55-67. 2010.

[86] Pande, S.K. and Udar, R. Genus Riccia in India. I. A reinvestigation of the taxonomic status of the Indian species of Riccia. Journal of the Indian Botanical Society 36: 564-579. 1957.

[87] Bir, S.S. and Chopra, R.N. Thallose liverworts from Dalhousie, North Western Himalayas. The Bryologist 75: 371-372. 1972.

[88] Daniels, A.E.D. Checklist of the bryophytes of Tamil Nadu, India. Archive for Bryology 65: 1-117. 2010.

[89] Frey, W. Die Lebermoose des Iran und Afghanistans. The Bryologist 77: 48-56. 1974

[90] Hattori S. Hepaticae. In: Hara, H. (ed.) The flora of Eastern Himalaya, second report. University of Tokyo press, Japan. pp. 222-240. 1971.

[91] Staples, G.W. and Imada, C.T. Checklist of Hawaiian Anthocerotes and Hepatics. Tropical Bryology 28: 15-47. 2006.
[92] Söderström, L. Gradstein, S.R. and Hagborg, A. Checklist of the hornworts and liverworts of Java. Phytotaxa 9: 53149. 2010.

[93] Yamada, K. and Iwatsuki, Z. Catalogue of the hepatics of Japan. Journal of the Hattori Botanical Laboratory 99: 1106. 2006 .

[94] Yamada, K. and Choe, D.M. A checklist of hepaticae and anthocerotae in the Korean peninsula. Journal of the Hattori Botanical Laboratory 81: 281-306. 1997.

[95] Manju, C.N., K.P. Rajesh and Prakashkumar, R. On the identity of Riccia fluitans (Ricciaceae: Marchantiophyta) in India. Acta Biologica Plantarum Agriensis 2: 117-126. 2012.

[96] Kachroo, P. Distribution of liverworts in Assam. Science \& Culture 18: 284-285. 1952.

[97] Kachroo, P. and Bapna, K.R. On some recently described species of Riccia from India. Proceedings of the National Institute of Sciences of India 29 B: 244-256. 1963.

[98] Manju C. N., Rajesh, K.P. and Madhusoodnan, P.V. Bryophytes of Wayanad in Western Ghats. Calicut, Malabar Natural History Society, Kerala. 2005.

[99] Bhattacharyya, P.K. Bryophyte flora of Bardhaman District, West Bengal. Bulletin of the Botanical Survey of India 47: 11-42. 2005.

[100] Pande, S.K and Srivastava, K.P. The hepatic vegetation of Pachmarhi (Madhya Pradesh): A preliminary survey. Journal of the Indian Botanical Society 31: 342-351. 1952.

[101] Barbhuiya, H.A. and Singh, S.K. 2012. Liverwort and Hornwort of Borail Wild Life Sanctuary, Assam, India. Archive for Bryology 134: 1-12.

[102] Wang, J., Lai, M.J. and Zhu, R.L. Liverworts and hornworts of Taiwan: an updated checklist and floristic accounts. Annales Botanici Fennici 48: 369-395. 2011.

[103] Bapna, K.R. and Vyas, G.G. Studies in the liverworts of Mount Abu (India) I. A preliminary account. Journal of the Hattori Botanical Laboratory 25: 81-90. 1962.

[104] Meijer, W. Notes on some species of Riccia from Malaysian region. Journal of the Hattori Botanical Laboratory 20: 107-118. 1958.

[105] Patidar, K.C. A note on the distribution of bryophytes in Indore, Madhya Pradesh. Journal of Economic and Taxonomic Botany 12: 467-468. 1988.

[106] Bapna, K.R. and Kachroo, P. Hepaticology in India II. Himanshu Publication, Delhi. 2000.

[107] Singh, D.K. and Singh, S.K. Diversity in Liverworts and Hornworts of Great Himalayan NationalPark, Western Himalaya, India. In: H. Mohamed, B.B. Baki, A. Nasrulhaq-Boyce \& P.K.Y. Lee (eds.), Bryology in the New Millennium. Kuala Lumpur: University of Malaya, pp. 57-82. 2008.

[108] Udar, R, Studies in Indian Ricciaceae -1. Proceedings of the $37^{\text {th }}$ Indian Science Congress, part III, p. 40 . 1950 . 